\title{
Performance of CVL-1 Seedling Growth and Dry Weight Attributes Under Greenhouse and Field Conditions as Affected By Seed Source and Seedling Age
}

\section{Md. Mahbubul Islam ${ }^{\triangleright}$ \\ Jannatul Ferdous ${ }^{2}$ Manika Rani Debnath ${ }^{3}$}

Chief Scientific Officer and Agronomy Division of Bangladesh Jute Research Institute, Dhaka. Bangladesh.

'Email:mahbubagronomy@yahoo.com Tel:+8801552416537

${ }^{2, s}$ Scientific Officer, Agronomy Division of Bangladesh Jute Research Institute, Dhaka. Bangladesh.

Email: tonny.jannat92@gmail.com Tel: +8801552999149

${ }^{3}$ Email: manika00474@vahoo.com Tel: +8801718232744

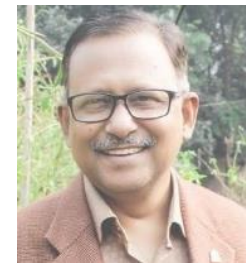

( Corresponding Author)

\begin{abstract}
Experiments were conducted to evaluate the plant establishment of white jute (Corchorus capsularis L.) seeds collected from five different sources of Bangladesh. The experiments were conducted at greenhouse of Bangladesh Jute Research Institute (BJRI), Dhaka and field of Jute Agriculture Experimental Station (JAES), BJRI, Manikganj during March to June 2018. The treatments consisted of five seed sources viz., i) BJRI, ii) Bangladesh Agriculture Development Corporation (BADC), iii), iv) Farmers of two locations and v) Local market. Farmers source was divided into two sub-sources (farmer1 of Manikganj and farmer2 of Kishoreganj locations). Two different conditions were i) Greenhouse and ii) Field. The four seedling ages were 30, 40, 50, and 60 days. The cv. CVL-1 was used as study material. Randomized completely block design with three replication were followed. Results revealed that seedling growth and dry weight parameters varied significantly due to seed sources. The shoot height, base diameter, root length, shoot dry weight and root dry weights varied significantly due to seed sources in both the condition of greenhouse and field. BJRI and BADC sources showed better performance than the others. The attributes showed significant variations for seedling ages in both the conditions also. The highest values were observed in 60 days of seedling age. The interactions of seed sources and seedling ages were highly significant for all the growth and dry weight attributes. The BJRI seeds of 60 days of age performed the highest shoot height, base diameter, root length, shoot dry weight and root dry weights. Seeds from BJRI and BADC of the CVL-1 varieties showed better performances in terms of seedling growth and dry weight compared to seeds from farmers' and local markets.
\end{abstract}

Keywords: White Jute (Corchorus capsularis L.), seedling ages, Shoot length, root length, Base diameter, Shoot dry weight, Root dry weight.

Citation | Md. Mahbubul Islam; Jannatul Ferdous; Manika Rani Debnath (2019). Performance of CVL-1 Seedling Growth and Dry Debnath (2019). Performance of CVL-1 Seedling Growth and Dry
Weight Attributes Under Greenhouse and Field Conditions as Weight Attributes Under Greenhouse and Field Conditions as
Affected By Seed Source and Seedling Age. Agriculture and Food Sciences Research, 6(1): 109-113.

History:

Received: 6 March 2019

Revised: 2 April 2019

Accepted: 8 May 2019

Licensed: This work is licensed under a Creative Commons Attribution 3.0 License (cc)

Publisher: Asian Online Journal Publishing Group
Contribution/Acknowledgement: All authors contributed to the conception and design of the study.

Funding: The research article is funded by institute (Bangladesh Jute Research Institute).

Competing Interests: The authors declare that they have no conflict of interests.

Transparency: The authors confirm that the manuscript is an honest, accurate, and transparent account of the study was reported; that no vital features of the study have been omitted; and that any discrepancies from the study as planned have been explained.

Ethical: This study follows all ethical practices during writing.

\section{Contents}

1. Introduction

References 


\section{Contribution of this paper to the literature}

This study contributes to existing literature by evaluating the plant establishment of white jute (Corchorus capsularis L.) seeds collected from five different sources of Bangladesh.

\section{Introduction}

Jute (Corchorus spp.) is one of the main cash crops of Bangladesh. It plays an important role earning about 5$6 \%$ foreign exchange through exporting jute and jute goods. Jute is a common term used both for plant and the fibre obtained from the bark of the plants, Corchorus capsularisL. and Corchorus olitoriusL. It covers about $2.86 \%$ of total cropped area. Bangladesh annually covering about 0.761 millions ha of land by jute crop to produce about 1.62 millions ton of fibre. The farmers require about 5500 tons of seed to cultivate the said area [1]. Bangladesh produces world's best quality jute. The agriculture climate of Bangladesh is very much suitable for quality fibre production. As a result supply of quality jute seed will ensure the fibre quality as well as quantity to a great extent. The government of Bangladesh has given more thrust to promote the jute seed industry by strengthening public sectors dealing with jute seed and also by sensitizing private sectors to reduce the dependence on imported jute seed. The activities of private sectors regarding jute seed are limited on seed import only [2].

Bangladesh requires about 5,000 metric tons of jute seeds of which only $12-15 \%$ is produced and distributed by Bangladesh Agricultural Development Corporation [3]. The rest of seeds is solely produced and utilized by the farmers'. The quality of farmers' seed is not maintained during production, processing and storage. In many cases, farmers' collect their seeds from their friends or neighbors and thus, there is no specific system to control the quality of seeds. Hence, it is conceived that the quality of seeds produced by majority of the farmers' is of low standard. Also, there is very little information regarding the level of farmers' knowledge on the production of jute seed and method of quality testing before sowing. Farmers' sometimes get good germination and good crop, but in most cases they get poor germination and a poor crop, and occasionally seeds do not germinate which results in total crop failure [4-6].

The quality status of jute seed at farm level is very poor and farmers' are normally ignorant of seed quality and quality evaluating tests. Farmers' are not aware of the germination percentage, vigor value, pathogens associated with seeds and percentage of moisture in their seeds. Although, there are many researches on the quality of the seed, no effort has yet been made to evaluate the quality of seed at farm level despite $75 \%$ of the total requirements of the jute seed are solely produced and distributed by the farmers'. If it is possible to address and appreciate the seed growers about their seed problems and help understand them to assess quality of jute seeds, they could establish it as a profitable enterprise [7, 8]. Seeds from BJRI and BADC of both the jute varieties showed better quality in terms of vigor and pathogen incidence compared to seeds from farmers' and local markets [9].

Jute seed quality does not vary only from farmer to farmer, but also from source-to-source. Information relating to viability, vigour and emergence of jute seed are very scanty under Bangladesh condition. Moreover, the category and extent of jute seed quality through seedling emergence and establishment of different sources are yet to be elucidated. The present study was, therefore, undertaken to evaluate the performances of seedling growth of white jute and their interactions as influenced by seed sources and seedling age.

\section{Materials and Methods}

The experiments were conducted at the Crop Management Laboratory, Agronomy division of Bangladesh Jute Research Institute (BJRI). The emergence experiment was conducted at Crop Management Laboratory, Agronomy Division of Bangladesh Jute Research Institute (BJRI), Dhaka as Greenhouse and at field of Jute Agriculture Experimental Station, Manikgonj of BJRI during March to June 2017. The treatments consisted of five seed sources viz., i. BJRI, ii. Bangladesh Agricultural Development Corporation (BADC), iii., iv) farmers of two locations and v. local market. The farmers seed source was divided into two sub-sources. The sub sources were farmer 1 of Manikganj and farmer2 of Kishoreganj locations. The seed sample variety CVL-1 of Corchorus capsularis L. was used as study material. Primary seed samples of $250 \mathrm{~g}$ each from all sources and from 20 farmers of each location were collected randomly. All the primary seed samples were mixed thoroughly to make a composite sample of each location. From the composite samples $500 \mathrm{~g}$ seeds were taken and regarded as submitted sample. The submitted seed samples were kept in brown paper bags. All the seed samples collected from the different seed sources were labeled properly and preserved in Gene Bank of BJRI at $20^{\circ} \mathrm{C}$ till the samples were used for studies. Working seed samples were taken from the preserved seed samples as per requirement. Total procedure was maintained following the rules of ISTA (International Seed Testing Association) [10]. Local market seed samples were collected and processed as that of farmers source of two locations. After collection of seed samples following tests were conducted.

The soil of field opened with power tiller in the month of Mid February, then the land was prepared with the country spade. The Laboratory greenhouse soil was prepared and managed as per recommendation of BJRI. The land was made free from weeds and plant debris by hand collection. During final plot preparation NPK fertilizers were applied in the form of urea, triple super phosphate and muriate of potash. The rates of fertilizers used were 83-25-30-11 kg of NPKS ha-1, respectively. Half quantity of $\mathrm{N}$ and the whole quantity of $\mathrm{P}, \mathrm{K}$ and $\mathrm{S}$ were applied as basal dose. The other half quantity of $\mathrm{N}$ was top dressed in two equal splits at 15 DAS.

Seeds used for the experiments had minimum of $80 \%$ germination. Seeds were sown on 25 March and 26 March in greenhouse and in the field, respectively. For each unit plot 500 seeds of each sample sources were sown in broadcast method and later covered with soil. In establishment test, 30, 40, 50 and 60-day-old seedlings were randomly collected from the greenhouse laboratory and as well as from field. The data of seedling shoot length, base diameter, root length, shoot dry weight and root dry weight of the seedlings were collected. Treatment mean differences were adjudged by DMRT following level of significance (0.05 and 0.01\%) [11].

\section{Results and Discussion}

Results revealed that at greenhouse, seedling height, base diameter, root length, shoot dry weight and root dry weights differed significantly due to seed sources for the variety CVL-1 at greenhouse conditionTable 1 . The 
highest seedling height, base diameter, root length, shoot dry weight and root dry weights $(103.75 \mathrm{~cm}, 10.75 \mathrm{~mm}$ and $12.20 \mathrm{~cm}, 8.13 \mathrm{~g}$ and $3.02 \mathrm{~g}$, respectively) were recorded in BJRI seeds, which were statistically similar to BADC seeds except root length. The lowest seedling height, base diameter and root length were recorded in farmers seed of Manikgonj Table 1. The farmers seed of Manikgonj and Kishoregonj; and market seed had statistically equal seedling height, base diameter, root length, shoot dry weight and root dry weights, the variation was found in seedling height Table 1

Irrespective of seed sources seedling height, base diameter, root length, shoot dry weight and root dry weights of CVL-1 varied significantly due to different seedling age at fieldTable 1. Except root dry weight all others showed statistical similarity in BJRI and BADC seeds. Seedling shoot dry weight and root dry weight were highest in BJRI seeds followed by BADC. The lowest Seedling shoot dry weight of farmers seed of Kishoreganj, and root dry weight of farmers seed of Manikganj; and stem dry weight in farmers seed of Manikganj and root dry weight in market seed were recorded. In terms of seed stem dry weight BADC seed showed statistical similarity with farmers and local market seeds Table 1. Under field condition significant variations were found in shoot and root dry weight among the seed sources of CVL-1 Table 1. Statistical similarity observed in BJRI and BADC seeds in terms of seedling shoot and root dry weight. The shoot dry weight and root dry weights were highest in BJRI seeds followed by BADC. The lowest shoot and root dry weight were observed in farmers seed of Manikganj. Local market seeds had the third highest shoot and root dry weights among the seed sources. The seedling shoot dry weight of market seed had similarity with BJRI and BADC seeds Table1. Development of a normal seedling from the seed is an essential requirement in the maintenance of seed viability. A normal seedling essentially should have a well-developed root system, some intact hypocotyls, two cotyledonary leaves and plumule with developing green leaves [5].

\begin{tabular}{|c|c|c|c|c|c|c|c|c|c|c|}
\hline \multirow{2}{*}{$\begin{array}{c}\text { Seed } \\
\text { sources }\end{array}$} & \multicolumn{5}{|c|}{ At greenhouse } & \multicolumn{5}{|c|}{ At field } \\
\hline & $\begin{array}{c}\text { Seedling } \\
\text { height } \\
(\mathrm{cm})\end{array}$ & $\begin{array}{c}\text { Base } \\
\text { diameter } \\
(\mathrm{mm})\end{array}$ & $\begin{array}{c}\text { Root } \\
\text { length } \\
(\mathrm{cm})\end{array}$ & $\begin{array}{c}\text { Shoot } \\
\text { dry } \\
\text { weight } \\
\text { (g) }\end{array}$ & $\begin{array}{c}\text { Root } \\
\text { dry } \\
\text { weight } \\
\text { (g) }\end{array}$ & $\begin{array}{c}\text { Seedling } \\
\text { height } \\
(\mathrm{cm})\end{array}$ & $\begin{array}{c}\text { Base } \\
\text { diameter } \\
(\mathrm{mm})\end{array}$ & $\begin{array}{c}\text { Root } \\
\text { length } \\
(\mathrm{cm})\end{array}$ & $\begin{array}{c}\text { Shoot } \\
\text { dry } \\
\text { weight } \\
\text { (g) }\end{array}$ & $\begin{array}{c}\text { Root dry } \\
\text { weight } \\
\text { (g) }\end{array}$ \\
\hline BJRI & $103.75 \mathrm{a}$ & $10.75 \mathrm{a}$ & $12.20 \mathrm{a}$ & $8.13 \mathrm{a}$ & $3.02 \mathrm{a}$ & $99.33 \mathrm{a}$ & $10.18 \mathrm{a}$ & $11.74 \mathrm{a}$ & 6.94 & $2.83 \mathrm{a}$ \\
\hline BADC & $101.25 \mathrm{a}$ & $10.39 \mathrm{a}$ & $11.65 \mathrm{~b}$ & $7.88 \mathrm{ab}$ & $2.79 \mathrm{a}$ & $96.58 \mathrm{a}$ & $9.83 \mathrm{~b}$ & $11.21 \mathrm{a}$ & 7.41 & $2.76 \mathrm{a}$ \\
\hline Farmer1 & $84.25 \mathrm{~cd}$ & $8.72 \mathrm{c}$ & $10.79 \mathrm{c}$ & $7.04 \mathrm{c}$ & $2.39 \mathrm{c}$ & $83.08 \mathrm{c}$ & $8.27 \mathrm{e}$ & $9.78 \mathrm{c}$ & 6.13 & $2.29 \mathrm{c}$ \\
\hline Farmer2 & $86.58 \mathrm{c}$ & $9.03 \mathrm{bc}$ & $10.98 \mathrm{c}$ & $6.92 \mathrm{~d}$ & $2.55 \mathrm{bc}$ & $86.50 \mathrm{bc}$ & $8.48 \mathrm{~d}$ & $10.01 \mathrm{bc}$ & 6.47 & $2.43 \mathrm{bc}$ \\
\hline $\begin{array}{c}\text { Local } \\
\text { market }\end{array}$ & $91.42 \mathrm{~b}$ & $9.36 \mathrm{~b}$ & $10.90 \mathrm{c}$ & $7.23 \mathrm{~b}$ & $2.66 \mathrm{~b}$ & $89.08 \mathrm{~b}$ & $8.71 \mathrm{c}$ & $10.37 \mathrm{~b}$ & 6.65 & $2.49 \mathrm{~b}$ \\
\hline
\end{tabular}

Irrespective of seed sources the seedling age showed significant differences in respect of seedling height, base diameter, root length, seedling shoot and root dry weights at field of the variety CVL-1 at greenhouse condition Table 2. The highest seedling heights base diameter and root length were $156.40 \mathrm{~cm}, 15.97 \mathrm{~mm}, 15.92 \mathrm{~cm}, 18.97 \mathrm{~g}$ and $7.94 \mathrm{~g}$, respectively. The lowest were observed at 30 DAS. The seedling height, base diameter and root length increased with the increase of seedling age. Significant differences were observed under seedling age regarding seedling height, base diameter and root length of CVL-1 due to seed sources Table 2. The highest seedling height, base diameter, root lengths, shoot dry weight and root dry weights were observed at 60 days of seedling age. The lowest seedling height, base diameter and root length were $45.40 \mathrm{~cm}, 4.91 \mathrm{~mm}, 7.19 \mathrm{~cm}, 1.03 \mathrm{~g}$ and $0.34 \mathrm{~g}$, respectively, were observed at 30 days of seedling age at greenhouse. A chronological increase was found in seedling height, base diameter and root length with the increase of seedling age from 30 to 60 days at an interval of 10 days Table 2 . The highest seedling height, base diameter, root length, seedling shoot and root dry weight, were found at 60 days after sowing (DAS) at field. The highest seedling height, base diameter and root length were found in BJRI seeds, which were similar to BADC seeds except base diameter. The farmer's seed of Manikganj had the lowest values for these parameters, which were similar to farmer's seed of Kishoreganj especially for seedling height at field condition Table 2. Local market seeds showed a little bit higher performance than farmers seeds. Local market seeds produced similar seedling height as that of farmers' seed of Kishoreganj Table 2. Irrespective of seed sources seedling age differed significantly regarding seedling shoot dry weight and root dry weight in CVL-1 Table2. Gradual increases were found in shoot and root dry weight with the increase of seedling age. In terms of shoot and root dry weight the variations among the seedling age were very high. The highest seedling shoot dry weights were found at 60 days and root dry weights were recorded in both the years at 60 DAS. The lowest shoot dry weight and root dry weights were found at 30 DAS Table2. Seedling age significantly affected the shoot and root dry weights in CVL-1 under field condition irrespective of seed sources. Gradual increases were found in seedling shoot and root dry weight with the increase of seedling age. Very high variations among the duration were recorded in shoot and root dry weight at field condition also. The highest shoot and root dry weights were observed at 60 DAS, while it was the lowest at 30 DAS Table 2.

Table-2.Effect of seedling characters of CVL-1 under greenhouse and field condition

\begin{tabular}{|c|c|c|c|c|c|c|c|c|c|c|}
\hline \multirow{2}{*}{$\begin{array}{c}\text { Seedling } \\
\text { age } \\
\text { (Days) }\end{array}$} & \multicolumn{5}{|c|}{ At greenhouse } & \multicolumn{5}{|c|}{ At field } \\
\hline & $\begin{array}{c}\text { Seedling } \\
\text { height } \\
(\mathrm{cm})\end{array}$ & $\begin{array}{c}\text { Base } \\
\text { diameter } \\
(\mathrm{mm})\end{array}$ & $\begin{array}{c}\text { Root } \\
\text { length } \\
(\mathrm{cm})\end{array}$ & $\begin{array}{c}\text { Shoot } \\
\text { dry } \\
\text { weight } \\
(\mathrm{g})\end{array}$ & \begin{tabular}{|c|} 
Root \\
dry \\
weight \\
(g)
\end{tabular} & $\begin{array}{c}\text { Seedling } \\
\text { height } \\
(\mathrm{cm})\end{array}$ & $\begin{array}{c}\text { Base } \\
\text { diameter } \\
(\mathrm{mm})\end{array}$ & $\begin{array}{c}\text { Root } \\
\text { length } \\
(\mathrm{cm})\end{array}$ & $\begin{array}{c}\text { Shoot } \\
\text { dry } \\
\text { weight } \\
\text { (g) }\end{array}$ & $\begin{array}{c}\text { Root } \\
\text { dry } \\
\text { weight } \\
\text { (g) }\end{array}$ \\
\hline 30 & $45.40 \mathrm{~d}$ & $4.91 \mathrm{~d}$ & $7.19 \mathrm{~d}$ & $1.03 \mathrm{~d}$ & $0.34 \mathrm{~d}$ & $38.80 \mathrm{~d}$ & $4.53 \mathrm{~d}$ & $6.71 \mathrm{~d}$ & $0.97 \mathrm{~d}$ & $0.33 \mathrm{~d}$ \\
\hline 40 & $68.87 \mathrm{c}$ & $6.96 \mathrm{c}$ & $10.18 \mathrm{c}$ & $2.78 \mathrm{c}$ & $0.79 \mathrm{c}$ & $67.47 \mathrm{c}$ & $6.37 \mathrm{c}$ & $10.00 \mathrm{c}$ & $2.56 \mathrm{c}$ & $0.78 \mathrm{c}$ \\
\hline 50 & $103.13 \mathrm{~b}$ & $10.76 \mathrm{~b}$ & $11.92 \mathrm{~b}$ & $6.98 \mathrm{~b}$ & $1.66 \mathrm{~b}$ & $101.00 \mathrm{~b}$ & $10.44 \mathrm{~b}$ & $11.43 \mathrm{~b}$ & $6.48 \mathrm{~b}$ & $1.93 \mathrm{~b}$ \\
\hline 60 & $156.40 \mathrm{a}$ & $15.97 \mathrm{a}$ & $15.92 \mathrm{a}$ & $18.97 \mathrm{a}$ & $7.94 \mathrm{a}$ & $154.44 \mathrm{a}$ & $15.03 \mathrm{a}$ & $14.35 \mathrm{a}$ & $16.88 \mathrm{a}$ & $7.21 \mathrm{a}$ \\
\hline
\end{tabular}

Note: In a column figures having common letter(s) do not differ significantly by DMRT at $1 \%$ level of probability. DAS= days after sowing. 
The interaction between seed sources and seedling age affected the seedling height, base diameter, root length, shoot dry weights and root dry weights significantly for CVL-1 at greenhouse Table 3. The highest seedling height, base diameter, root length, shoot dry weight and root dry weights were recorded $(167.33 \mathrm{~cm}, 17.23 \mathrm{~mm}$, $16.77 \mathrm{~cm}, 20.61 \mathrm{~g}$ and $8.91 \mathrm{~g}$, respectively) in BJRI seeds at 60 days seedling age. The lowest seedling height and base diameter $(41.00 \mathrm{~cm}$ and $4.03 \mathrm{~mm}$, respectively) were observed in farmers' seed of Manikgonj with 30 days seedling age. At 30 days seedling age, was statistically identical to farmers' seed of Manikgonj and market seed Table 3. BADC seeds showed statistically identical results to BJRI. The seedling shoot and root dry weights were the lowest in farmers seed of Manikgonj and in local market seed and in farmers seed of Kishoregonj at 30 DAS. Farmers' seed of both Manikgonj and Kishoregonj; and market seeds showed statistical similarity as regard to seedling age Table 3 .

Seedling height, base diameter, root length, seedling shoot and root dry weights of CVL-1 under field condition were significantly affected by the interaction between seed sources and seedling age. The highest seedling height, base diameter, root length, seedling shoot and root dry weights were observed in BJRI seeds at 60 days of seedling age followed by BADC seeds.

In farmers seed of Manikganj the lowest values for these parameters were found at 30 DAS. Seedling height, base diameter and root length observed under greenhouse condition were higher than those at the field Table 3. BADC seeds had statistical similarity with BJRI seed. The seedling shoot and root dry weights were lowest at 30 DAS in farmers seed of Manikgonj. Similar root dry weight was observed in farmers' seed of Kishoregonj. Farmers' seed of both the locations and market seed's had shoot and root dry weights statistically indifferent Table 3. Results are in agreement with Islam [5] and Islam [9].

Table-3.Interaction effect of seed sources and seedling age on seedling growth characters of CVL-1 under green house and field.

\begin{tabular}{|c|c|c|c|c|c|c|c|c|c|c|c|}
\hline \multirow{2}{*}{\multicolumn{2}{|c|}{$\begin{array}{c}\text { Seed sources } \\
\text { and seedling } \\
\text { age(days) }\end{array}$}} & \multicolumn{5}{|c|}{ At greenhouse } & \multicolumn{5}{|c|}{ At field } \\
\hline & & $\begin{array}{c}\text { Seedling } \\
\text { height } \\
(\mathrm{cm})\end{array}$ & $\begin{array}{c}\text { Base } \\
\text { diameter } \\
(\mathrm{mm})\end{array}$ & $\begin{array}{c}\text { Root } \\
\text { length } \\
(\mathrm{cm})\end{array}$ & $\begin{array}{c}\text { Shoot } \\
\text { dry wt } \\
(\mathrm{g})\end{array}$ & $\begin{array}{c}\text { Root } \\
\text { dry wt } \\
\text { (g) }\end{array}$ & $\begin{array}{c}\text { Seedling } \\
\text { height } \\
(\mathrm{cm})\end{array}$ & $\begin{array}{c}\text { Base } \\
\text { diameter } \\
(\mathrm{mm})\end{array}$ & $\begin{array}{c}\text { Root } \\
\text { length } \\
(\mathrm{cm})\end{array}$ & $\begin{array}{l}\text { Shoot } \\
\text { dry wt } \\
\text { (g) }\end{array}$ & $\begin{array}{c}\text { Root } \\
\text { dry wt } \\
\text { (g) }\end{array}$ \\
\hline \multirow[t]{4}{*}{ BJRI } & 30 & $51.00 d$ & $6.00 d$ & $8.13 \mathrm{~cd}$ & $1.13 \mathrm{~d}$ & $0.40 d$ & $44.67 \mathrm{~d}$ & $5.43 \mathrm{~d}$ & $7.7 \mathrm{Od}$ & $1.05 \mathrm{~d}$ & $0.39 \mathrm{~d}$ \\
\hline & 40 & $81.33 \mathrm{c}$ & $7.97 \mathrm{c}$ & $11.13 \mathrm{c}$ & $2.98 \mathrm{c}$ & $0.85 \mathrm{c}$ & $76.62 \mathrm{c}$ & $7.37 \mathrm{c}$ & $10.60 b c$ & $2.98 \mathrm{c}$ & $0.85 \mathrm{c}$ \\
\hline & 50 & $115.33 \mathrm{~b}$ & $11.80 \mathrm{~b}$ & $12.77 \mathrm{~b}$ & $7.82 \mathrm{~b}$ & $1.92 \mathrm{~b}$ & $112.00 \mathrm{~b}$ & $11.40 \mathrm{ab}$ & $12.61 \mathrm{~b}$ & $7.56 \mathrm{~b}$ & $2.03 \mathrm{~b}$ \\
\hline & 60 & $167.33 \mathrm{a}$ & $17.23 \mathrm{a}$ & $16.77 \mathrm{a}$ & $20.61 \mathrm{a}$ & $8.91 \mathrm{a}$ & $164.00 a$ & $16.53 \mathrm{a}$ & $16.07 \mathrm{a}$ & $18.56 \mathrm{a}$ & $8.06 \mathrm{a}$ \\
\hline \multirow[t]{4}{*}{ BADC } & 30 & $48.67 \mathrm{~d}$ & $5.83 \mathrm{~d}$ & $7.67 \mathrm{~d}$ & $1.09 \mathrm{~d}$ & $0.38 \mathrm{~d}$ & $43.32 \mathrm{~d}$ & $5.20 \mathrm{~d}$ & $7.30 d$ & $0.98 \mathrm{~d}$ & $0.37 \mathrm{~d}$ \\
\hline & 40 & $79.00 \mathrm{c}$ & $7.67 \mathrm{c}$ & $10.50 \mathrm{c}$ & $2.90 \mathrm{c}$ & $0.83 \mathrm{c}$ & $74.00 \mathrm{c}$ & $7.10 \mathrm{c}$ & $10.17 \mathrm{bc}$ & $2.88 \mathrm{c}$ & $0.81 \mathrm{c}$ \\
\hline & 50 & $113.00 \mathrm{~b}$ & $11.33 \mathrm{~b}$ & $12.33 \mathrm{~b}$ & $7.49 \mathrm{~b}$ & $1.85 \mathrm{~b}$ & $108.63 \mathrm{~b}$ & $11.13 \mathrm{~b}$ & $12.10 b$ & $7.12 \mathrm{~b}$ & $2.01 \mathrm{~b}$ \\
\hline & 60 & $164.33 \mathrm{a}$ & $16.73 \mathrm{a}$ & $16.10 \mathrm{a}$ & $20.06 \mathrm{a}$ & $8.08 \mathrm{a}$ & $160.34 a$ & $15.87 \mathrm{a}$ & $15.27 \mathrm{a}$ & $16.94 \mathrm{a}$ & $7.87 \mathrm{a}$ \\
\hline \multirow[t]{4}{*}{ Farmer 1} & 30 & $41.00 d$ & $4.03 \mathrm{~d}$ & $6.77 \mathrm{~d}$ & $0.96 \mathrm{~d}$ & $0.29 \mathrm{~d}$ & $33.32 \mathrm{~d}$ & $3.77 \mathrm{~d}$ & $6.20 d$ & $0.88 \mathrm{~d}$ & $0.29 \mathrm{~d}$ \\
\hline & 40 & $59.33 \mathrm{c}$ & $6.27 \mathrm{~cd}$ & $9.77 \mathrm{dc}$ & $2.62 \mathrm{c}$ & $0.73 \mathrm{c}$ & $59.00 \mathrm{c}$ & $5.63 \mathrm{c}$ & $9.33 \mathrm{c}$ & $2.10 \mathrm{c}$ & $0.7 \mathrm{Oc}$ \\
\hline & 50 & $94.00 \mathrm{~b}$ & $10.03 \mathrm{~b}$ & $11.4 \mathrm{Ob}$ & $6.74 \mathrm{~b}$ & $1.15 \mathrm{~b}$ & $92.33 \mathrm{~b}$ & $9.70 \mathrm{~b}$ & $10.60 b$ & $5.58 \mathrm{~b}$ & $1.79 \mathrm{~b}$ \\
\hline & 60 & $142.67 \mathrm{a}$ & $14.53 \mathrm{ab}$ & $15.23 \mathrm{a}$ & $17.86 \mathrm{a}$ & $7.39 a$ & $147.65 \mathrm{a}$ & $13.96 \mathrm{a}$ & $13.00 \mathrm{a}$ & $15.97 \mathrm{a}$ & $6.39 a$ \\
\hline \multirow{4}{*}{ Farmer2 } & 30 & $42.00 d$ & $4.20 d$ & $6.63 \mathrm{~d}$ & $0.98 \mathrm{~d}$ & $0.31 \mathrm{~d}$ & $34.67 \mathrm{c}$ & $3.93 \mathrm{~d}$ & $5.97 \mathrm{~d}$ & $0.95 \mathrm{~d}$ & $0.29 \mathrm{~d}$ \\
\hline & 40 & $62.00 \mathrm{c}$ & $6.30 \mathrm{c}$ & $9.77 \mathrm{c}$ & $2.68 \mathrm{c}$ & $0.75 \mathrm{c}$ & $62.00 \mathrm{c}$ & $5.76 \mathrm{c}$ & $9.83 \mathrm{c}$ & $2.26 \mathrm{c}$ & $0.75 \mathrm{c}$ \\
\hline & 50 & $93.33 \mathrm{~b}$ & $10.17 \mathrm{~b}$ & $11.80 \mathrm{~b}$ & $6.28 \mathrm{~b}$ & $1.69 \mathrm{~b}$ & $95.67 \mathrm{~b}$ & $9.90 \mathrm{~b}$ & $10.83 \mathrm{~b}$ & $6.00 \mathrm{~b}$ & $1.89 \mathrm{~b}$ \\
\hline & 60 & 149.00a & $15.47 \mathrm{a}$ & $15.73 \mathrm{a}$ & $17.74 \mathrm{a}$ & $7.46 \mathrm{a}$ & $153.63 \mathrm{a}$ & $14.33 a$ & $13.40 a$ & $16.67 \mathrm{a}$ & $6.81 \mathrm{a}$ \\
\hline \multirow{4}{*}{$\begin{array}{c}\text { Local } \\
\text { market }\end{array}$} & 30 & $44.33 \mathrm{~d}$ & $4.50 \mathrm{~d}$ & $6.77 \mathrm{~d}$ & $1.00 d$ & $0.32 \mathrm{~d}$ & $38.00 d$ & $4.30 \mathrm{~d}$ & $6.40 d$ & $0.98 \mathrm{~d}$ & $0.32 \mathrm{~d}$ \\
\hline & 40 & $62.67 \mathrm{c}$ & $6.60 \mathrm{c}$ & $9.77 \mathrm{c}$ & $2.74 \mathrm{c}$ & $0.79 \mathrm{c}$ & $65.62 \mathrm{c}$ & $6.00 \mathrm{c}$ & $10.07 \mathrm{bc}$ & $2.56 \mathrm{c}$ & $0.78 \mathrm{c}$ \\
\hline & 50 & $100.00 b$ & $10.47 b$ & $11.3 \mathrm{ob}$ & $6.56 \mathrm{~b}$ & $1.68 \mathrm{~b}$ & $96.33 \mathrm{~b}$ & $10.07 \mathrm{ab}$ & $11.00 \mathrm{~b}$ & $6.13 \mathrm{~b}$ & $1.93 \mathrm{~b}$ \\
\hline & 60 & $158.67 \mathrm{a}$ & $15.87 \mathrm{a}$ & $15.77 \mathrm{a}$ & $18.61 \mathrm{a}$ & $7.87 \mathrm{a}$ & $156.31 \mathrm{a}$ & $14.47 \mathrm{a}$ & $14.00 a$ & $16.17 \mathrm{a}$ & $6.94 \mathrm{a}$ \\
\hline
\end{tabular}

Note: In a column figures having common letter(s) do not differ significantly by DMRT at $1 \%$ level of probability

\section{Conclusion}

CVL-1 seed's seedling growth varied significantly due to seed sources and seedling age. The seedling height, base diameter, root length, shoot dry weight and root dry weights for seedling establishment of CVL-1 seed's varied significantly due to seed sources in both the condition of green house and field.

The interaction of seed sources and seedling ages were highly significant and the BJRI seeds of 60 days age showed the highest plant height, base diameter, root length, shoot dry weight and root dry weights. Seeds from BJRI and BADC of the CVL-1 varieties showed better performances in terms of seedling growth and dry weight compared to seeds from farmers' and local markets.

\section{References}

[1] BBS, Yearbook of agricultural Statistics of Bangladesh. Dhaka, Bangladesh: Ministry of Planning, Government of the People's Republic of Bangladesh, 2015.

[2] M. M. Islam and N. Uddin, "Research and development advances of jute seed in Bangladesh: A review," Haya: The Saudi Journal of Life Sciences, vol. 4, pp. 52-68, 2019.

[3] M. Salim, M. A. Hannan, M. A. R. Sarkar, and M. Ali, "Seed quality in late seed crop as affected by late sowing," Bangladesh JournalSeed Science and Technology, vol. 2, pp. 11-17, 1998.

[4] M. A. Hossain, S. A. Mannan, K. Sultana, and A. L. Khandakar, "Survey on the constrains of quality jute seed at farm level," Research Report., Agriculture. Support Serv. Proj., Bangladesh Jute Res. Inst., Dhaka, Bangladesh, pp. 45-50. 1994.

[5] M. M. Islam, Jute seed technology, 1st ed. Mohamadpur, Dhaka: Pub. by Md. Mahmudul Islam, 397, Middle Monipur, Mirpur, Dhaka-12 16. College Gate Book Binding and Printing, College Gate, Dhaka, Bangladesh. pp. 120. 2009.

[6] M. M. Islam, "Technological advances in off-season jute seed production," Journal of Experimental Biosciences, vol. 1, pp. 75-82, 2010 .

[7] M. M. Islam, M. A. R. Sarkar, M. Ahmed, S. M. A. Hossain, and S. M. Moniruzzaman, "Evaluation of jute seed quality attributes and their relationship as affected by seed sources," Bangladesh Journal Jute and Fib. Reserces, vol. 28, pp. 31-38, 2008.

[8] M. M. Islam, M. A. R. Sarkar, M. Ahmed, S. M. Moniruzzaman, and M. N. Uddin, "Germination, vigour and emergence indicators of Corchorus olitorius L, seed and their relationship as influenced by seed sources," Bangladesh Journal Jute and Fib. Reserces, vol. 29, pp. 1-8, 2009. 
[9] M. M. Islam, "Seed quality of two Corchorus spp. collected from different sources in Bangladesh," Journal of Agricultural Technology Management, vol. 19, pp. 1-11,2016.

[10] ISTA (International Seed Testing Association), "International rules for seed testing," Seed Science and Technology, vol. 13, pp. 356$513,1985$.

[11] A. K. Gomez and A. A. Gomez, Statistical procedures for agricultural research, 2nd ed. New York: John Wiley and Sons Inc, pp. 124. 1984 . 